\title{
Meta-Analysis on the Effect of Zinc on Reducing Diarrhea Episode in Toddlers
}

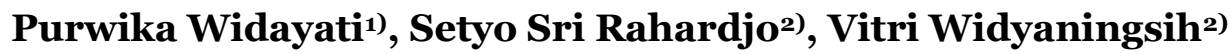 \\ 1)Masters Program in Public Health, Universitas Sebelas Maret \\ ${ }^{2)}$ Faculty of Medicine, Universitas Sebelas Maret
}

\begin{abstract}
Background: Diarrhea is a major cause of mortality and morbidity in toddlers in the world. A number of studies have shown that zinc supplements can reduce the severity and duration of diarrhea in toddlers. This study aimed to examine the effectiveness of zinc on reducing diarrhea episode in toddlers.

Subjects and Method: This was a meta-analysis conducted using PRISMA systematic guideline. Articles published between year 2000 and 2019 were selected from PubMed, Science Direct, and Springer Link databases. Six articles met the Randomized Controlled Trial (RCT) criteria. These studies were conducted in developing countries. A sample of 692 children divided into two groups of 348 zinc and 344 placebo. The data were analyzed by Review Manager (RevMan) 5.3 program. The results were assessed for Mean difference (MD) and the analysis was carried out for heterogeneity.

Results: There was a high heterogeneity between experiments ( $\mathrm{I} 2=91 \% ; \mathrm{p}<0.001)$ so that Random Effects Model (REM) was used. Zinc administration reduced the duration of diarrhea 0.89 days faster than placebo, and it was statistically significant $(\mathrm{MD}=-0.89 ; 95 \% \mathrm{CI}=-1.52$ to $-0.26 ; \mathrm{p}=$ o.006).
\end{abstract}

Conclusion: Zinc supplementation is more effective than placebo in reducing the duration of diarrhea in children.

Keywords: effectiveness, zinc, diarrhea, toddlers, meta analysis

\section{Correspondence:}

Purwika Widayati. Masters Program in Public Health, Universitas Sebelas Maret. Jl. Ir. Sutami 36A, Surakarta 57126, Central Java. Email: purwika15@gmail.com. Mobile: o81231153131.

\section{BACKGROUND}

Diarrhea is a major cause of mortality and morbidity and is a major cause of malnutrition in toddlers in the world. In 2017, around 525,000 children die from diarrhea (WHO, 2017). Deaths due to diarrhea occur among children less than 2 years who live in South Asia and Sub-Saharan Africa (UNICEF, 2018).

Diarrhea was usually a symptom of a gastrointestinal infection that can be caused by bacteria, viruses and parasites. Infection spreads through contaminated food or drinking water, can also spread from person to person due to poor personal hygiene. Severe diarrhea might lead to loss of fluids and can cause mental loss especially in children and people who were malnourished or have weak immunity, diarrhea can be prevented and treated (WHO, 2016).

The cause of diarrhea is a virus (rota virus); bacteria, including Shigella, Salmonella, Esheresia choli, Vibrio, and stomach parasites (worms). Diarrhea is transmitted through food or drinks contaminated with bacteria. The shoot period is very acute and short, from several hours to several days (between 8 hours to 5 days), depending on the cause of the illness (Pudiastuti, 2011).

Poor behavior can also be a means of transmitting diarrhea. For example the 
habit of defecating in an open place which resulted in polluting the water, polluting the soil, and becoming a place to flies. Not washing hands or washing hands without soap. Not using clean water facilities. In children, diarrhea was usually caused by parasites, bacterial infections or viruses, antibiotics, or food (Pudiastuti, 2011).

Zinc tablets: micronutrients that function in cell growth, as antioxidants, form the body's immunity, and perform intestinal functions. Zinc in infants less than 2 months was given at a dose of $10 \mathrm{mg} /$ day for 10 days. In children, zinc was given at a dose of $20 \mathrm{mg} /$ day for 10 days. Giving zinc according to dosage can reduce the intensity of subsequent diarrhea. WHO recommended zinc in diarrhea to accelerate healing and prevent complications such as chronic diarrhea and malnutrition. However, it turned out the benefits of zinc are not only obtained when children experienced acute diarrhea. Zinc given to persistent diarrhea also has the same effect (Prihaningtyas, 2014).

Zinc soluble salts in gluconate and sulfate/acetate were used as supplements in the form of tablets or syrup to prevent zinc deficiency and to treat diarrhea in children (Wegmüller et al., 2014). Over the past 10 years, more than 40 zinc sulphate randomized controlled trials (RCTs) have been carried out in developing countries around the world (Duke, 2011).

Study by Galvao explained that the prevalence on days 3,5 and 7 was lower in the zinc recipient group than in the control group (Galvao et al., 2013).

This study aimed to examine the effectiveness of zinc use compared to placebo in reducing the duration of diarrhea in children in developing countries.

\begin{abstract}
SUBJECTS AND METHOD

\section{a. Study Design}

This study was a systematic review and meta-analysis. Study data was sought from a systematic and comprehensive database of several indexes including; PubMed, Science Direct, and Springer Link. The keywords used for database searches were "diarrhea in children", "zinc and placebo", "probiotics and placebo", "zinc and probiotic", "diarrhea and randomized control trials".
\end{abstract}

\section{b. Inclusion Criteria}

The inclusion criteria in this study were full paper articles with Randomized Controlled Trial (RCT). The therapy given was zinc (gluconate, sulfate, and acetate) with a comparison of placebo. The study subjects were toddlers (o-6o months) with diarrheal disease. The dosage given is $\geq 20 \mathrm{mg} /$ day. Articles were published in English.

\section{c. Exclusion Criteria}

The study was conducted in cross sectional (cross sectional), case control (case control), quasi experimental. The study subjects were toddlers with chronic diarrhea. Therapy was given zinc with other additions. The control group was not a placebo.

\section{d. Definition Operational of Variables}

Diarrhea was a change in bowel habits, indicated by an increase in frequency (defecation more than 3 times 1 day) marked changes in feces from solid to liquid occur less than 14 days in toddlers or diarrhea that occurred more than 14 days in infants. Provision of zinc supplements was dose $<20$ $\mathrm{mg} /$ day or $\geq 20 \mathrm{mg} /$ day.

This study involved two treatment groups to be compared. The zinc group included gluconate, sulfate, and acetate and the control group was placebo. The measurement scale of results from zinc and placebo was the duration of diarrhea.

\section{e. Study Instrument}

Published articles between year 2000 and 2019 were selected in developing countries 
from PubMed, Science Direct, dan Springer Link databases.

\section{f. Data Analysis}

Data analysis was carried out using the Review Manager (Rev-Man) software 5.3 released by the Cochrane Collaboration. RevMan was used to calculate Mean Difference (MD) as a whole.

\section{RESULTS}

There were 606 articles identified can be seen in Figure 1. After going through the process of deleting multiple articles found 32 articles then the article filtered 574 articles. Based on the results of the filtered

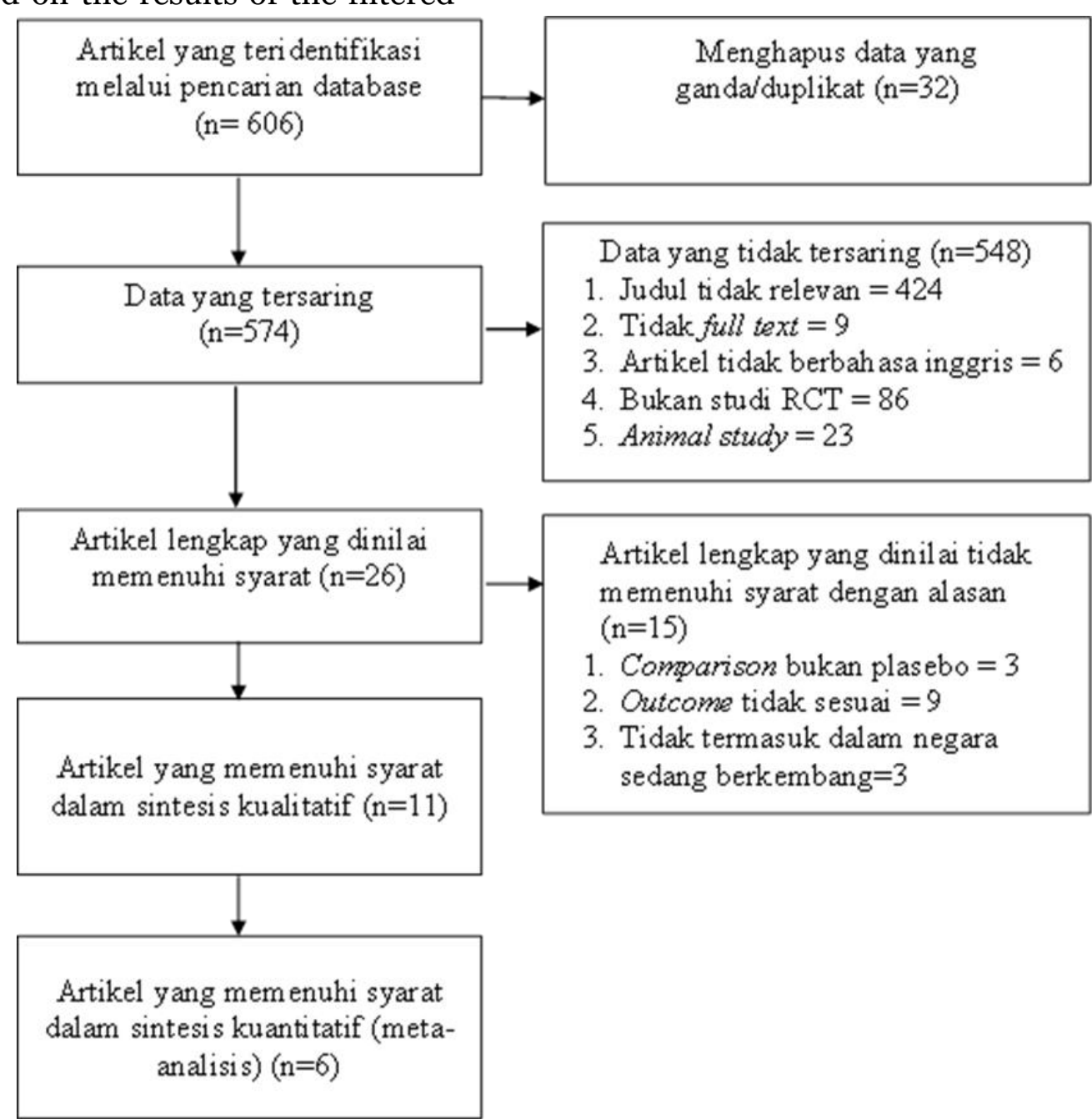

Figure 1. Flowchart of Review Process

Comparison in the study obtained was not placebo but with zinc, non-placebo, article, there were 548 articles that had to be issued and 26 articles that were considered fulfilling the requirements for subsequent full text review process.

After an assessment of full text articles, there were some articles that were not targeted for toddlers but for children over the age of 5 years old. Outcomes from the study did not meet the requirements because it was not the duration of diarrhea but the frequency of diarrhea, volume of diarrhea, body weight, complications after treatment, satisfaction after treatment, and others.
3. Artikel tidak berbah asa inggris $=6$

4. Bukan studi $\mathrm{RCT}=86$

5. Animal study $=23$

Artikel lengkap yang dinilai tidak memenuhi syarat dengan al asan $(\mathrm{n}=15)$

1. Comparison bukan plasebo $=3$

Outcome tidak sesuai $=9$

Tidak termasuk dalam negara dang berkembang $=3$ 
hospital. Giving therapy was not to children for less than 5 years. Published articles were not included in developing countries, such as Italy, the United States, Poland and Australia.

Articles that fulfill the qualitative requirements were reviewed and one article was issued because it did not include the average after treatment and standard deviation (SD) needed to determine the effects of treatment. The article only included the difference in improvement after treatment so that analysis cannot be done using the mean difference (MD).

The final results of the article review process contained six articles that fulfilled the quantitative requirements for a metaanalysis of the effectiveness of zinc administration in the management of diarrhea in children. Articles obtained from the review were studies originating from countries belonging to developing countries. The following was an overview of the study area obtained from articles that have fulfilled the requirements: there was one study conducted in Brazil, Turkey, Bangladesh, Peru and India.

It can be seen that in the lower middle income countries that were included in this meta-analysis consisted of Brazil, Turkey, Bangladesh, Peru and India. The country of Brazil included in the subject of this study consisted of 37 children receiving zinc and 37 children receiving a placebo. The Turkish state involved 60 children receiving zinc and 60 children receiving a placebo. The Bangladesh state involved 86 children receiving zinc and 89 children receiving placebo. The country of Peru involved 80 children who received zinc and 79 children received a placebo. India involved 85 children received zinc and 79 children received placebo.

The results of the meta-analysis were presented in the form of a forest plot. The forest plot was a diagram that showed information from each study studied and estimates of overall results (Akobeng in Murti, 2018). In addition to the forest plot, this meta-analysis also showed that the funnel plot was a diagram that illustrated the possibility of publication bias by displaying relations between the size of the effect and the sample size of the various studies. The publication bias in the funnel plot can be assessed by looking at the funnel shape asymmetry, the number of points on the right and left side compared to the standard error (Murti, 2018).

Based on the articles identified from the review results, 6 articles fulfilled the requirements as a source for the metaanalysis of the effectiveness of zinc use compared to placebo in reducing the duration of diarrhea in children. Next the articles that have been obtained would be analyzed by using RevMen 5.3 and the results would be presented in the form of a forest plot which can be seen in Figure 2. 
Widayati et al./ Meta-analysis on the effect on Zinc on reducing diarrhea Table 1. Summary Source of the Effectiveness of Using Zinc in the Management of Diarrhea in Children

\begin{tabular}{|c|c|c|c|c|c|c|}
\hline \multirow{2}{*}{ Author (Years) } & \multirow{2}{*}{ Country } & \multicolumn{2}{|c|}{ Type and Dosage } & \multirow{2}{*}{ Inclusion Criteria } & \multicolumn{2}{|c|}{ Result } \\
\hline & & Zinc & Placebo & & Zinc & Placebo \\
\hline (Dutta et al., 2000) & India & $40 \mathrm{mg}$ zinc & ORS & $\begin{array}{l}\text { The study subjects were children } \\
\text { aged 3-24 months old at Dr. B.C. } \\
\text { Roy Memorial Hospital of Kolkata } \\
\text { City in India, giving therapy more } \\
\text { than } 3 \text { days. }\end{array}$ & $\begin{array}{l}\text { Mean: } 2.93 \\
\text { SD: } 0.41\end{array}$ & $\begin{array}{l}\text { Mean: } 4.3 \\
\text { SD: } 0.71\end{array}$ \\
\hline (Al-Sonboli et al., & Brazil & $25 \mathrm{mg}$ zinc & Lactobacillus & Study on toddlers, the study was & Mean: $3 \cdot 3$ & Mean: 3.7 \\
\hline 2003） & & & GG & $\begin{array}{l}\text { conducted at Joao Alves Hospital, } \\
\text { giving therapy for more than } 3 \\
\text { days. }\end{array}$ & SD: 2.0 & SD: 2.0 \\
\hline (Mary et al., 2004) & Peru & $\begin{array}{l}20 \text { mg zinc } \\
\text { gluconate }\end{array}$ & micronutrient & $\begin{array}{l}\text { Study in Shanty Hospital, Peru, } \\
\text { the subject of study were children } \\
\text { aged 6-35 months old, giving } \\
\text { therapy for more than } 3 \text { days. }\end{array}$ & $\begin{array}{l}\text { Mean: } 2.7 \\
\text { SD: } 1.1\end{array}$ & $\begin{array}{l}\text { Mean: } 2.7 \\
\text { SD: } 1.1\end{array}$ \\
\hline (Brooks et al., 2005) & Bangladesh & $\begin{array}{l}20 \mathrm{mg} \text { zinc } \\
\text { acetate }\end{array}$ & $5 \mathrm{ml}$ placebo & $\begin{array}{l}\text { The study was conducted on } \\
\text { children aged 1-6 months old, } \\
\text { performed at the hospital. }\end{array}$ & $\begin{array}{l}\text { Mean: } 5 \\
\text { SD: } 4.6\end{array}$ & $\begin{array}{l}\text { Mean: } 5 \\
\text { SD: } 4.6\end{array}$ \\
\hline (Dutta et al., 2011) & India & $20 \mathrm{mg}$ zinc & Micronutrient & $\begin{array}{l}\text { This study was in children aged 6- } \\
24 \text { months old, it was conducted } \\
\text { at Dr. B.C. Roy Memorial } \\
\text { Hospital, Kolkata City in India }\end{array}$ & $\begin{array}{l}\text { Mean: } 2.49 \\
\text { SD: } 0.67\end{array}$ & $\begin{array}{l}\text { Mean: } 3.67 \\
\text { SD: } 0.95\end{array}$ \\
\hline (Dalgic et al., 2011) & Turkey & $\begin{array}{l}20 \mathrm{mg} \text { zinc } \\
\text { acetate }\end{array}$ & ORS & $\begin{array}{l}\text { The study was conducted at Sisli } \\
\text { Etfal Training and study Hospital, } \\
\text { the Study subjects aged 1-28 } \\
\text { months old }\end{array}$ & $\begin{array}{l}\text { Mean: } 3 \cdot 41 \\
\text { SD: } 1.38\end{array}$ & $\begin{array}{l}\text { Mean: } 5 \cdot 35 \\
\text { SD: } 1.80\end{array}$ \\
\hline
\end{tabular}


The results of the analysis in Figure 2. can be seen that 6 articles reported that zinc administration was one way to reduce the duration of diarrhea in children. Based on the results of the analysis, there was a high heterogeneity between experiments (I2 = 91\%; p <0.001) so that Random Effects Model (REM) was used. Giving zinc was able to reduce the duration of diarrhea by o.89 days faster than giving placebo, and it Zinc Placebo

was statistically significant (MD -o.89; CI $95 \%-1.52$ to -0.26 ).

Based on figure 3 , the plot of zinc used plots in the management of diarrhea, plots on the right and left sides were not symmetrical with each other and did not form an inverted funnel. The left plot has a standard error $>0.2$ and the right plot has a standard error $>0.6$, this indicated that there was publication bias in the study.

\begin{tabular}{|c|c|c|c|c|c|c|c|c|c|c|c|}
\hline \multirow[b]{2}{*}{ Study or Subgroup } & \multicolumn{3}{|c|}{ Zinc } & \multicolumn{3}{|c|}{ Placebo } & \multirow{2}{*}{\multicolumn{3}{|c|}{$\begin{array}{c}\text { Mean Difference } \\
\text { Weight IV, Random, } 95 \% \mathrm{Cl}\end{array}$}} & \multirow{2}{*}{\multicolumn{2}{|c|}{$\begin{array}{l}\text { Mean Difference } \\
\text { IV, Random, } 955 \mathrm{Cl}\end{array}$}} \\
\hline & Mean & SD & Total 1 & Mean & SD & Total & & & & & \\
\hline Al-Sonboli 2003 & 3.3 & 2 & 37 & 3.7 & 2 & 37 & $14.3 \%$ & $-0.40[-1.31,0.51]$ & & $\longrightarrow$ & \\
\hline Brooks 2005 & & 4.6 & 86 & 5 & 4.6 & 89 & $10.4 \%$ & $0.00[-1.36,1.36]$ & & & \\
\hline Dalgic 2011 & 3.41 & & 60 & 5.35 & 1.8 & 60 & $17.4 \%$ & $-1.94[-2.51,-1.37]$ & & $\rightarrow$ & \\
\hline Dutta 2000 & 2.93 & & 44 & 4.308 & 0.71 & 36 & $19.6 \%$ & $-1,38[-1.64,-1.12]$ & & + & \\
\hline Dutta 2011 & 2.49 & & 41 & 3.67 & 0.958 & 43 & $19.1 \%$ & $-1.18[-1.53,-0.83]$ & & $\rightarrow$ & \\
\hline Mary 2004 & 2.7 & 1.1 & 80 & 2.7 & 1.1 & 79 & $19.2 \%$ & $0.00[-0.34,0.34]$ & & + & \\
\hline Total $(95 \%$ CI) & & & 348 & & & 344 & $100.0 \%$ & $\cdot 0.89[-1.52,-0.26]$ & & & \\
\hline $\begin{array}{l}\text { Heterogeneity, Tau } \|^{2} \text { : } \\
\text { Test for overall effect }\end{array}$ & $\begin{array}{l}0.51 ; \mathrm{Ch} \\
z=2.76\end{array}$ & & & $=5(\mathrm{P} \&$ & 0.0000 & (1); $\left.\right|^{2}=$ & $91 \%$ & & & ${ }^{0}{ }^{2}$ & 2 \\
\hline
\end{tabular}

Figure 2. Forest plot of zinc administration in reducing diarrhea episode

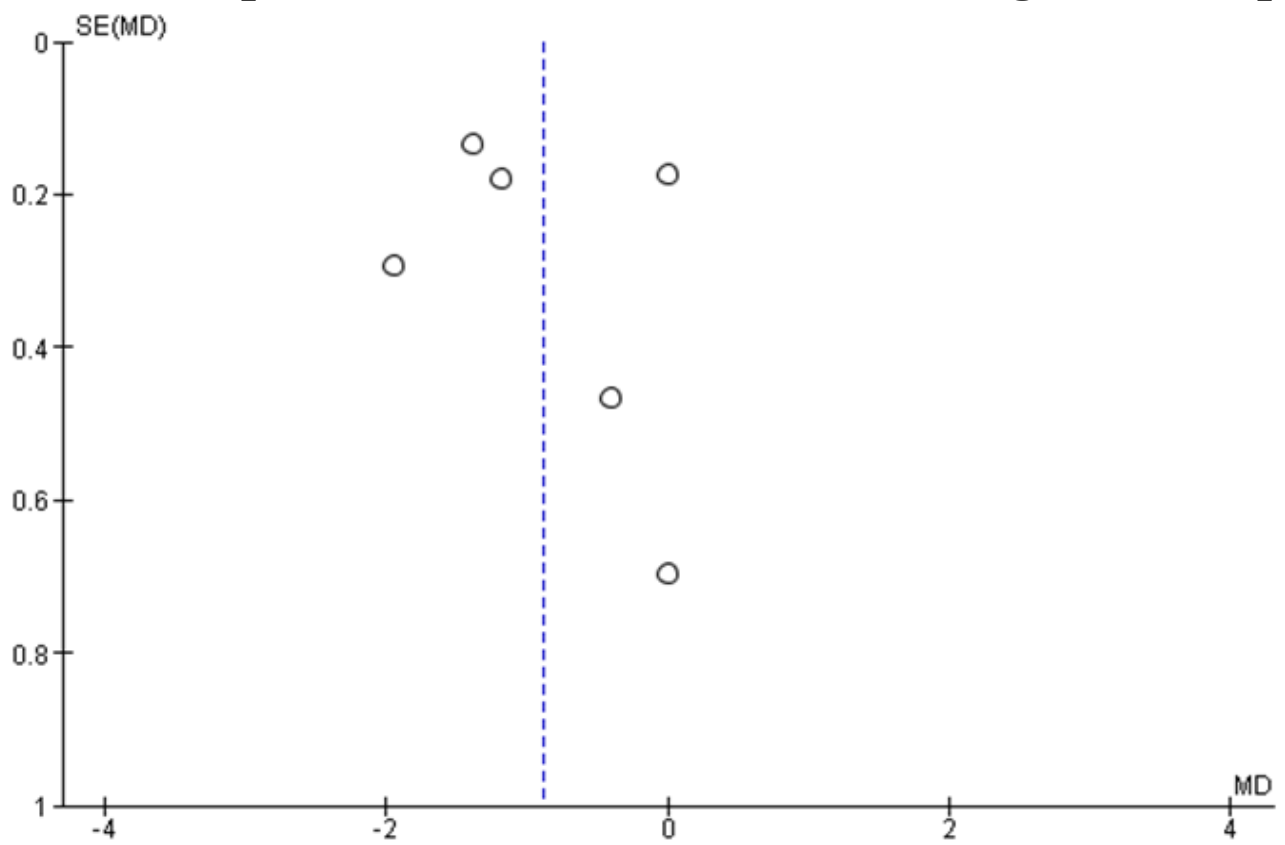

Figure 3. Funnel plot of zinc administration in reducing diarrhea episode 


\section{DISCUSSIONS}

$\overline{\text { Diarrhea was a major cause of malnutrition }}$ and death in children under five (Tungga et al., 2018). About 525.000 of child deaths every year due to diarrhea (Susanti, 2018). Diarrhea was the leading cause of death among infants and children in underdeveloped and developing countries (Agegnehu et al., 2019). Better management of diarrhea and prevention of hospital-acquired diarrhea were important for reducing mortality (Grenov et al., 2019). Diarrhea was most common in toddlers (Zicof et al., 2018).

Zinc supplements during diarrhea were currently recommended by the World Health Organization (WHO) and the United Nations Children's Fund (UNICEF) (Lazzerini, 2016). Zinc was needed for physiological processes including defense against infection. Zinc deficiency was responsible for up to $4 \%$ of global child morbidity and mortality (Penny, 2013).

Based on the results of an analysis of 6 articles regarding the duration of diarrhea in zinc use and placebo, it was reported that zinc administration was one way to reduce the duration of diarrhea in children. Based on the results of the analysis, there was a high heterogeneity between experiments $\left(I^{2}=91 \% ; p<0.001\right)$ so that Random Effects Model (REM) was used. Giving zinc was able to reduce the duration of diarrhea by 0.89 days faster than giving placebo, and it was statistically significant (MD -0.89; 95\% $\mathrm{CI}=-1.52$ to -0.26 ).

The results were supported by Lukacik et al., (2008) which showed that zinc supplements reduced the duration of diarrhea and the severity of acute diarrhea and persistent diarrhea. A study by Yazar et al. (2016) showed that zinc supplementation reduced the duration of diarrhea, with better clinical results at 72 and 96 hours, and both can be used in children with acute diarrhea.
Study done by Penny (2013) showed that there was a reduction of up to $9 \%$ in the duration of diarrhea. Zinc was also effective in reducing dysentery and exact diarrhea. Provision of zinc was estimated to reduce diarrhea deaths by $13 \%$, so it was advisable to make national-level programs in combating zinc deficiency in childhood, should be accelerated. The results of study done by Jiang et al. (2016) stated that oral zinc as an adjunctive therapy was effective in treating infants and young children with rotavirus enteritis, and reduced the incidence and incidence of recurrence of diarrhea in the next three months.

\section{AUTHOR CONTRIBUTIONS}

Purwika Widayati, the main author who played a role in collecting and processing study data; Vitri Widyaningsih examined the conceptual framework and study methodology and interpreted the results of data analysis; Setyo Sri Rahardjo wrote the interpretation of data analysis.

FUNDING AND SPONSORSHIP

This study did not use costs due to secondary data and used databases that can be accessed and provided open access journals.

\section{CONFLICT OF INTEREST}

The authors did not have any conflict of interest.

\section{ACKNOWLEDGEMENT}

The authors would like to thank Pubmed, Science Direct, and Springer Link databases for providing information and data to published journals.

\section{REFERENCE}

Agegnehu M, Zeleke L, Goshu Y, Ortibo Y, Mehretie AY (2019). Diarrhea pre- 
vention practice and associated factors among caregivers of under-five children in enemay district, Northwest Ethiopia. Journal of Environmental and Public Health: 1-8 doi: $10.1155 / 2019-/ 5490716$.

Al-Sonboli N, Gurgel R, Shenkin A, Hart C, Cuevas L (2003). Zinc supplementation in Brazilian children with acute diarrhea. Annals of Tropical Paediarics, 23(1): 3-8. doi: 10.1-179/000349803125002797.

Boran P, Tokuc G, Vagas E, Oktem S, Gokduman M (2006). Impact of Zinc Supplementation in Children with Acute Diarrhoea in Turkey. Archives of Disease in Childhood, 91(4): 296299. doi: 10.1136/adc.2005.-079-939.

Brooks W, Santosham M, Roy S, Faruque A, Wahed M, Nahar K, Khan A, Khan A, Fuchs G, Black R (2005). Efficacy of zinc in young infants with acute watery diarrhea. American Journal of Clinical Nutrition, 82(3): 605-610.

Dalgic N, Sancar M, Bayraktar B, Pullu M, Hasim O (2011). Probiotic, zinc and lactose-free formula in children with rotavirus diarrhea: are they effective?. Pediatrics International, 53(5): 677682. doi: 10.1111/j.1-442-200X.2011.03325.x.

Duke T (2011). Zinc sulphate for treatment and prevention of diarrhoea and other conditions in children in Papua New Guinea. Papua and New Guinea medical journal, 54(1-2): 17-22. Retrieved from http://www.ncbi.nlm.nih .gov/pubmed/23763035.

Dutta P, Mitra U, Dutta S, Naik T, Rajendran K, Chatterjee M (2011). Zinc, vitamin A, and micronutrient supplementation in children with diarrhea: a randomized controlled clinical trial of combination therapy versus monotherapy. Journal of Pediatrics. Mosby,
Inc, 159(4): 633-637. doi: 10.1016/j.jpeds.2011.03.028.

Galvao TF, Thees MF, Pontes RF, Silva MT, Pereira MG (2013). Zinc supplementation for treating diarrhea in children: a systematic review and meta analysis. Revista panamericana de salud publica $=$ Pan American journal of public health, 33(5): 370-7. doi: 10.1590/s1020-49892013000500009.

Grenov B, Lanyero B, Nabukeera-Barungi $\mathrm{N}$, Namusoke H, Ritz C, Friis H, Michaelsen K, Mølgaard C (2019). Diarrhea, dehydration, and the associated mortality in children with complicated severe acute malnutrition: a prospective cohort study in Uganda. The Journal of Pediatrics. Mosby. doi: 10.1016/J.JPEDS.2019.-03.014.

Jiang CX, Xu CD, Yang CQ (2016). Therapeutic effects of zinc supplement as adjunctive therapy in infants and young children with rotavirus enteritis. Zhongguo dang dai er ke za zhi = Chinese Journal of Contem-porary Pediatrics, 18(9): 826-830. Retrieved from http://www.ncbi.nlm.nih.gov/pubmed/27655538.

Lazzerini M (2016). Oral zinc provision in acute diarrhea. Current Opinion in Clinical Nutrition and Metabolic Care, 19(3): 1. doi: 10.1097/MCO.00000ooooooo0276.

Lukacik M, Thomas R, Aranda V (2008). A meta-analysis of the effects of oral zinc in the treatment of acute and persistent diarrhea. Pediatrics, 121-(2): 326-336. doi: 10.1542/peds.20070921.

Mary EP (2004). Randomized controlled trial of the effect of daily supplementation with zinc or multiple micronutrients on the morbidity, growth, and micronutrient status of young Peruvian Children. American Journal 
of Clinical Nutrition, 79(3): 457-465. Retrieved from http://ovidsp.ovid.com/ovidweb.cgi? $\mathrm{T}=\mathrm{JS} \& \mathrm{PAGE}=$ refere nce $\& \mathrm{D}=$ emed9 $\& \mathrm{NEWS}=\mathrm{N} \& \mathrm{AN}=41115$ 591.

Murti B (2018). Prinsip dan metode riset epidemiologi edisi ke empat (Fourth edition of epidemiology research principles and methods). Surakarta: Universitas Sebelas Maret.

Penny M (2013). Zinc Supplementation in Public Health. Annals of Nutrition and Metabolism. Karger Publishers, 62(s1): 31-42. doi: 10.1159/000348263.

Prihaningtyas RA (2014). Deteksi dan Cepat obati $30+$ penyakit yang sering menyerang anak (Detect and quickly treat $30+$ diseases that mostly attack children). Yogyakarta: Media Pressindo.

Pudiastuti RD (2011). Waspadai penyakit pada anak (Beware of diseases in children). Jakarta: Indeks.

Susanti E (2018). Risk factors for diarrhea cases in communities living along Deli River, North Sumatera. Journal of Epidemiology and Public Health, 04(01): 47-54. doi: 10.26911/jepublichealth.2019.04.01.06.

Tungga TM (2018). Path analysis: psychososial and economic factors affecting diarrhea incidence in children under five in Jayapura, Papua. Journal of Epidemiology and Public Health, 03(03): 331-341. doi: 10.26911/jepub- lichealth.2018.03.03.04.

UNICEF (2018). Diarrhoeal disease. Retrieved from https://-data.unicef.org/topic/child-health/diarrhoeal-disease/.

Wegmüller R, Tay F, Zeder C, Brnić M, Hurrell R (2014). Zinc absorption by young adults from supplemental zinc citrate is comparable with that from zinc gluconate and higher than from zinc oxide. The Journal of Nutrition, 144(2): 132-136. doi: 10.3945/jn.113.181487 .

WHO (2016). Diarrhoea. World Health Organization. Retrieved from https:// www.who.int-/topics/-diarrhoea/en/.

WHO (2017). Diarrhoeal disease Retrieved from http://www.who.int/en/newsroom/factsheets/detail/diarrhoealdise ase.

Yazar AS, Guven Ş, Dinleyici EÇ (2016). Effects of zinc or synbiotic on the duration of diarrhea in children with acute infectious diarrhea. Turkish Journal of Gastroenterology, 27(6): 537-540. doi: 10.5152/tjg.2016.16396.

Zicof E, Rahardjo SS, Murti B (2018). Multilevel analysis: biopsychosocial determinants and environmental factor on the incidence of diarrhea among children under five in Surakarta. Journal of Epidemiology and Public Health, 03(03): 323-330. doi: 10.26911/jepublichealth.2018.03.03.03. 